\title{
A
}

$\mathrm{R}$

$\mathrm{T}$

Y

K

$\mathrm{U}$

Ł

\section{FLOATING TERRITORIES OF RELIGION(S): SHIFTING PARADIGMS, ERRATIC THEORIES, AND VOLATILE REALITIES ${ }^{1}$}

Most scholars in religious studies, cultural studies, and social sciences, consciously and regularly promote the idea that the new shape of societies, cultures and religions is that of a world "in motion". But is it really so? It is obvious that our world, at whichever scale it is observed, is made of extensive circuits and institutional networks: the rapid diffusion of images and ideas, the numerous human flows (migrants, tourists, workers, ...) beyond the limits of borders, the displacement and relocation of production sites as seen in global economies, the reshaping of geopolitics and international relations, the emergence of a class of cosmopolitan travelers, and the foundation of supranational institutions for health and trade, most visibly and significantly illustrate the global forces applied onto the contemporary world ${ }^{2}$.

${ }^{*} \mathrm{PhD}$, professor in anthropology at the University of Lyon 2, France, fellow of the Institute of Advanced Studies of Strasbourg, France, 10 rue Monsieur le Prince, 75006 Paris, e-mail: Lionel.Obadia@univ-lyon2.fr

${ }^{1}$ Acknowledgement: This paper has been written thanks to a fellowship at the Institute of Advanced Studies of Strasbourg (USIAS).

${ }^{2}$ Malcolm Waters, Globalization, 2nd edition (London: Routledge, 2001). And Peter Beyer, "The Religious System of Global Society: a Sociological Look at Contemporary Religion and Religions," Numen 45(1998): 1-29. 
Other significant empirical data demonstrate the same diagnosis for religious traditions in the context of globalization: circulation, delocalization and relocation are processes experienced by religions every day. Buddhist ideas and techniques have been massively adopted in the West - a Western take on Eastern beliefs. Islam is turning more "Asian"; its demographic weight is nowadays mostly concentrated in Indonesia - although African and Middle-East countries remain associated with Islam in the Western imagination and beyond. Christian beliefs and practices are also shifting location: Christianity is becoming more "African" and "South American", and is consequently reshaped by "non-White" and non-Western cultures. Should also be mentioned the circulation, on a global scale, of "magical" techniques infusing the fields of visual and textual cultures (cinema, literature), of therapy (medical and alternative practices), and of art (general aesthetics).

Many other examples can also be presented as significant cases of religions "in motion" in the $20^{\text {th }}$ and $21^{\text {st }}$ centuries, i.e. at the heart of modern times and globalization processes: "local" ethnic cults, such as South-American Santo Daime, Santeria or Candomblé, are moving to Europe; Asian and North-American shamanistic traditions are being exported worldwide, as well-being techniques or as "management" methods in corporate settings; ancient cults, such as Druidism, are being reinvented and reaching an international audience in Great-Britain; Modern Satanism is spreading to Western countries (North-America and Europe), and gaining more followers beyond the boundaries of Christian grounds... And, finally, a new geography articulating religion and atheism is being drawn by the parallel expansion of missionary groups (whether Buddhist, Christian or Muslim), and non-religious atheist, agnostic or freethinking doctrines, growing concurrently both in terms of demography and visibility ${ }^{3}$.

As it turns out, all these empirical observations are, more or less directly, related to the issue of territoriality. In the context of "hypermodern times", individuals and groups are supposed to be impacted

${ }^{3}$ Phil Zuckerman (Ed.), Atheism and Secularity. Vol. 1: Issues, Concepts and Definitions (Santa-Barbara, Denver, Oxford: Praeger/ABC-Clio, 2010) and Vol. 2: Global Expressions (Santa-Barbara, Denver, Oxford, Praeger/ABC-Clio, 2010). 
by "global conditions". Few scholars however agree on what exactly constitutes these "global conditions" (whether they are of an economic, technological, cultural or political nature) and what kind of influence they have (whether they "destroy" or "consolidate" the world order) 4 . All in all, however, a widely shared position on globalization states that societies are "on the move" , and cultures are "traveling" Consequently, societies and cultures move within the broader picture of "globalization without borders"?

Considering the world as an open space that facilitates all sorts of circulations, resulting in infinite religious and cultural hybridizations $^{8}$ directly impacts the possible ways to theorize spatial grounds for religious traditions. Despite the late recognition of religious topics and issues in Global Studies, this subfield at the intersection between the latter and Religious Studies is developing quickly and massively ${ }^{9}$. Spatial themes rank among the prominent themes of Global Religious Studies. Yet, they are far from being the only ones: economic and cultural subject-matters, proselytism and conversion issues, the outcomes of religious encounters and hybridization processes, continuities and changes in religious systems and global systems... are common topics of discussion. Nevertheless, the transformation of the material foundations of religions, especially when it comes to their territorial inscriptions and/or the dislocations between space and religions, have become important chapters in this new narrative of the history of civilizations. Interestingly, it should be pointed out that territorial issues are emerging by default, rather than by excess of empirical reality and theoretical weight: the dynamics of deterritorialization (of cultures, societ-

${ }^{4}$ Mauro Guillén, "Is globalization civilizing, destructive or feeble? A critique of five key debates in the social science literature," Annual Review of Sociology 27(2002): 235-260.

${ }^{5}$ John Tomlinson, Globalization and Culture (Chicago: University of Chicago Press, 1999).

${ }^{6}$ James Clifford, "Travelling Cultures," in Cultural Studies, ed. Lawrence Grossberg et al. (New York: Routledge, 1992), 96-116.

${ }^{7}$ George Ritzer, The Globalization of Nothing (Thousand Oaks: Pine Forge Press,2004).

${ }^{8}$ Nathalie Luca, "Borrowings go Round and Round. Transcending Borders and Religious Flexibility," Diogenes 47/187 (1999): 3-10.

${ }^{9}$ Lionel Obadia, "Globalization and the Sociology of Religion," in The New Companion for the Sociology of Religion, ed. Bryan Turner (Oxford: Blackwell, 2010), 477-497. 
ies, religions) seem to overtake territorialization processes; scholars nowadays pay much more attention to what has been altered within traditions than to what is lasting through time. As such, deterritorialization processes are easily discernible proofs of the (alleged) effects of modernization and globalization.

Global Studies have consequently integrated the theory that cultural dynamics and their locations (and, by extension, religious dynamics and their locations), have become "unpredictable on a territorial basis"10. The processes that are responsible for these new religious kinetics can be labelled in various ways: "circulation", "transnationalization", "globalization", or "diffusion", are some of the terms from the vast array of concepts designed to describe mobility issues. But such an emphasis on movement, fluidity and circulation, paradoxically leaves little room for a spatial analysis register to develop. All in all, spatial issues are framed by default; and the concept of "deterritorialization" has shifted from the intellectual, philosophy-based matrix within which it was coined, to a geography-based theoretical and methodological framework ${ }^{11}$. The term has become a focal buzzword, and is mostly used as a conceptual tool to describe and analyze the effects of mobility processes in the context of globalization. Thomas Csordas typified these processes as "migration", "mission", and "mediatization" 12 . While it was communicated in other terms before, deterritorialization as a concept logically extends and encapsulates the idea that modernization and globalization have generated a quick, generalized and substantial fading of territories in the political sense of the term - as with the weakening of national control on borders, for instance. Moreover, it entails the disappearance of space in the anthropological sense of the term, i.e. as significant areas where identity and memory are produced and reproduced by means of social relationships ${ }^{13}$.

${ }^{10}$ Waters, Globalization, 5.

${ }^{11}$ Tomlinson, Globalization and Culture.

12 Thomas J. Csordas, "Modalities of transnational transcendence," in Modalities of transnational transcendence. Essays on Religion and Globalization, ed. Thomas J. Csordas (Berkeley, Los Angeles, London: University of California Press, 2009), 1-29.

${ }^{13}$ Marc Augé, Non-Lieux. Introduction à une anthropologie de la surmodernité (Paris: le Seuil, 1992). 
Deterritorialization turns out to be the most important effect of the globalization on cultures, societies and religions: it is the planetary, "apocalyptic" force of modernity bringing about major changes in ancient traditions. The so-called accelerated fading of traditions (although the acceleration is only true to a certain extent), used to be considered a consequence of modernization. Only recently has it been attributed to globalization. Indeed, modernization processes had been previously characterized by the "dilution" or "liquefaction" of traditional cultures and social structures ${ }^{14}$, destabilizing contemporary societies and affecting their territorial base. But deterritorialization, whether "modern" or "global", is an intellectually-construed category and as such, rather than being taken for granted per se, must be questioned.

Mobility issues cannot be limited to the spatial transformations of religion: it also calls for a shift in the ways religions are embedded in history, and in the narratives of religious change, especially as theoretically framed by academia. As a logical consequence, it is necessary to evaluate the models of religious mobility and of religious globalization (which are different processes), and the epistemological issues underlying this theoretical change; this can almost be considered a shift in paradigm, pertaining to "space" and "territory" in Religious Studies. At the very least, from the empirical front to the theoretical end, the topic of territory is steeped in fuzziness, and serves as a loose object on which theories, that can at best be qualified as vague, are built. Is vagueness the rule, then, when it comes to cultures, religions, and territories?

\section{A DECLINE OF 'SEDENTARY' APPROACHES TO CULTURES} AND SOCIETIES

To understand how this conclusion was reached, starting from the end rather than from the beginning is more efficient. In a programmatic article published in 2006, Hannam, Sheller and Urry devoted long pages

${ }^{14}$ George Balandier, Le détour (Paris: Fayard, 1985) and Zygmunt Bauman, "Identity in the globalising world," Social Anthropology, 9/02 (2001): 121-129. 
to empirical data and conceptual tools, to prove that social sciences were witnessing a "mobility turn"15. This idea was not new: it had been widely demonstrated before the three authors tackled it, that transportation and communication techniques, the complexity of informational networks, as well as people's nonchalant desire (as with tourists) or crucial need (as with refugees) to move and the redefinition of political borders, made the world more "open" to certain forms of nomadism, whether "traditional" or "modern". These observations bring an end to the "sedentary approaches" in social and cultural studies (and hence, in religious studies as well), making room for more dynamic, process-based, kinetic approaches to reality to be theorized - which is more in line with what reality is supposed to be. But as French philosopher Regis Debray put it, in a book on the techniques of information and modes of communication about God in history, there is "no kinetics without statics"16. In other words, movement cannot exist without motionlessness. A few years later, the same idea was defended by the leading promoter of the "mobility turn", John Urry, when he asserted that mobility created immobility and that scholars should not be solely focusing on the first and forgetting the latter ${ }^{17}$. For that reason, there should be no choosing between territorialization or deterritorialization approaches to religions: both should be simultaneously taken into account.

The emphasis upon movement, diffusion and deterritorialization, rather than fixity, cultural regionalism and spatial embeddedness, has captured the attention of scholars, and led to what has been labelled a truly revolutionary change of scope in the study of religion. Lily Kong, a prominent geographer at the University of Singapore, has asserted that a real 'theoretical shift' 18 in the ways scholars view and study religious phenomena is being witnessed: building on pioneering

${ }^{15}$ Kevin Hannam, Mimi Sheller, and John Urry, "Editorial: Mobilities, Immobilities and Moorings," Mobilities 1(2006): 1-22.

16 "Pas de cinétique sans statique", Régis Debray, Dieu, un itinéraire (Paris: Odile Jacob, 2001), 141.

${ }^{17}$ Hannam, Sheller and Urry, "Editorial."

${ }^{18}$ Lily Kong, "Mapping 'new' geographies of religion: politics and poetics in modernity,” Progress in Human Geography, 25/2 (2001): 211-233. 
works by Henri Lefebvre in the mid-1970s and Michel de Certeau in the 1980s, territories and spaces are now considered as processes and narratives. This has led to non-essentialist, constructivist representations of territories, and of the ways they are "fabricated" by culture and beliefs, sustained in time by means of social processes and policies, which transform and relocate under specific conditions. Considering that the effects of movement and mobility appear more discernible than those of stability and territoriality, Urry \& al. ${ }^{19}$ have suggested that the social sciences had entered a "mobility turn". Epistemologically speaking, it means the focus on "processes" and "mobility" gives shape to a new approach, and points at an effort to fashion a renewed viewpoint on cultural dynamics, with a critical slant on "sedentary approaches". Accordingly, American anthropologist Arjun Appadurai has asserted that scholars studying cultural and social aspects of globalization apply what he calls "a decisive shift from trait geographies to process geographies" ${ }^{20}$. He went on to observe that scholars, in Globalization Studies, seem more interested in studying dynamics than examining fixed form, and that Area Studies have therefore been sidestepped in favor of more processual items. Even in the context of academic geography, Lily Kong has alluded to "new mappings" of religion in "process" and "sensuous" geographies"

Is all this proof of a true shift in paradigm? Or is it only "yet another turn" among the many social sciences have (truly or allegedly) undertaken? Scholars' stances pan from enthusiasm to skepticism. Optimistic views on mobility and deterritorialization trends have already been highlighted. In order to counterbalance their intellectual weight, it is necessary to also put forward a few resistant views to this "turn". Systemic approaches to global phenomena, such as Jonathan Friedman's "Global Culture" model22, or the "Global Religion" model

${ }^{19}$ Hannam, Sheller and Urry, "Editorial."

${ }^{20}$ Arjun Appadurai, "Grassroots Globalization and the Research Imagination," in Globalization, ed. Arjun Appadurai (Durham, London: Duke University Press, 2001), 7.

${ }^{21}$ Lily Kong, "Global shifts, theoretical shifts: Changing geographies of religion," Progress in Human Geography 34/6 (2010): 755-776.

${ }^{22}$ Jonathan Friedman, Cultural Identity and Global Process (London: Sage, 1994). 
coined by Peter Beyer ${ }^{23}$ and deepened by Thomas $\operatorname{Csordas}^{24}$, altogether doubt the "mobility discourse": they emphasize the opposite effects of processive crystallization on physical soils, and of the existence of stable "structures" or "systems" beyond the apparent generalization of "flows". In a recent book tackling the emerging forms of a Global Religion, French sociologist Raphaël Liogier invited scholars to think beyond the model of "religious mobility", by admitting that a "Global Religion" could be a "religion of mobility", without necessarily being a "mobile religion" 25 .

It is nevertheless obvious that territorial issues are topical: they can be observed in all corners of the world, in violent or pacific contexts, and they strongly stimulate academic discussions and public debates, which do not only take place in highly-globalized modern Western societies. Religious issues, especially as they relate to sites and territories, are indeed "hot" topics. The contemporary world is full to the brim with conflicts and disputes for land considered sacred, with "religious invasions", whether real or imagined, with the destruction of religious sites as weapons of war, ... In parallel, the rise of creolization and the pluralization of religious landscapes can be observed. Territories are thought of as "sites" or "theaters", and facilitate the understanding of processes that differ in nature - circulation, transformative dynamics, hybridization... But as it has been said, a "mobility turn" goes with a "geographic turn" 26 , and territories can also be read as "maps" or "models" of cultural and religious realities.

In April 2013, a map was published in the French world affairs magazine "Courrier International", displaying a map of worldwide religious dynamics. On it, different areas are seen as torn between pluralization on the one hand, and fundamentalist pressures on the other. This particular representation of the world's religious landscape precisely locates sites where contemporary religious dynamics are salient. It can

${ }^{23}$ Peter Beyer, Religion and Globalization (London: Sage 1994).

${ }^{24}$ Thomas J. Csordas, "Modalities".

${ }^{25}$ Raphaël Liogier, Souci de soi, Conscience du Monde: vers une religion Globale? (Paris: Armand Colin, 2012), 49-50.

${ }^{26}$ Allison Blunt, "Cultural Geographies of Migration: Mobility, Transnationality and Diaspora," Progress in Human Geography 31/5 (2007): 684-694. 
however, as many others, be considered simplistic: it does not fully explain the complexity of the situation, i.e. that contrasting processes of diversification are being superimposed onto shared religious landscapes. It thereby misses the mark in clarifying the geographic collision between cultural and religious mixed spaces, on the one hand, and the unification of belief systems by Christian and Muslim fundamentalism (generally applied by forceful conversion) on the other.

\section{Les dynamiques religieuses dans le monde}

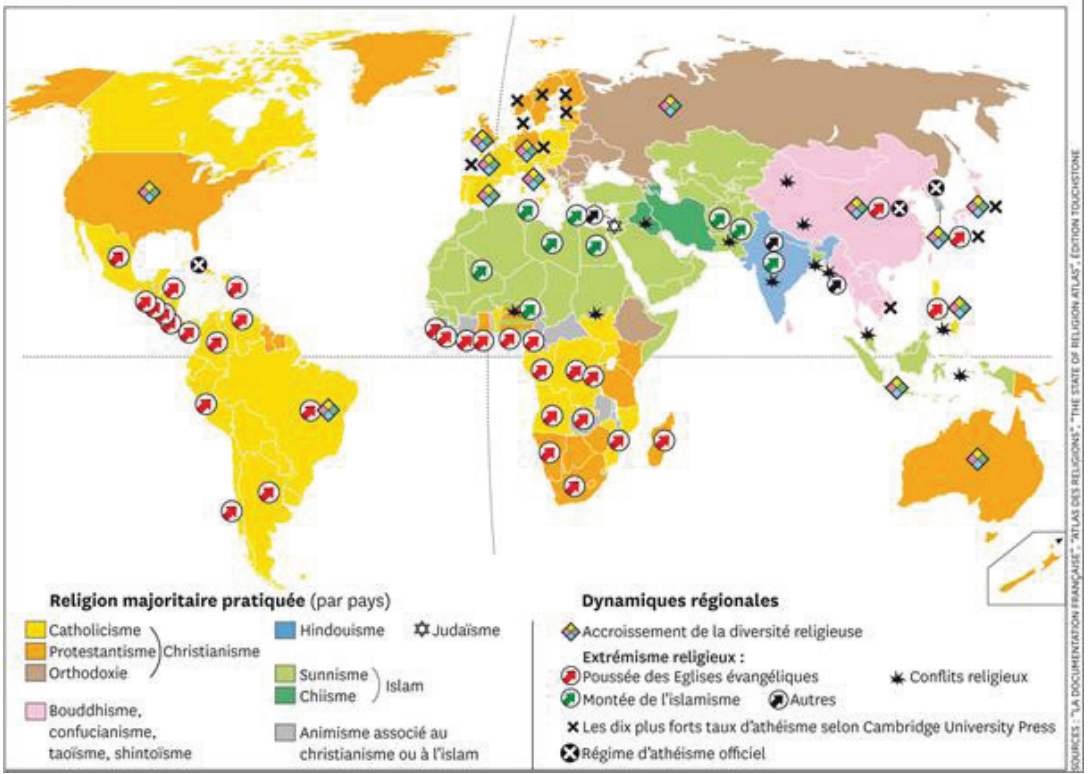

Like other such maps that have been drawn and published in the past, this particular one makes the reader believe that the world is divided into distinct regions. In some of these regions, religions are getting more diverse (densification and diversification in the North); in others, single religions are attempting to spread over and colonize new territories, antagonizing other traditions (dispersion and standardization in the South). The only exception appears to be Asian insular zones. It exhibits a specific model of religious dynamics in territories, and the transformation of territories. As such, although a simplified model of religious 
dynamics variations, it reveals the relevance of a geographic approach to religion in the context of globalization, on a macroscopic scale.

\author{
A REVENGE OF 'SPACE' AND 'TERRITORY' \\ IN RELIGIOUS STUDIES AND SOCIAL SCIENCES?
}

As evidenced empirically and theoretically, after being disqualified in the name of Modernity and Globalization, "space" and "territory" are coming back to the forefront of social sciences and religious studies' agendas. By avoiding both disproportionate conceptual doubt and excessive enthusiasm, and moving beyond the limitations of empirical grounds, it is obvious that territorial issues offer new and exciting conceptual frameworks. These new theoretical trends are outlined by excess of space. On the one hand, social sciences are going through a "Spatial Turn", both by focusing on geographic aspects of cultures and societies, as Doreen Massey put it ${ }^{27}$, and by widening perspectives in Religious Studies; and on the other hand, models to analyze space in Religious Studies are being developed by finding inspiration in philosophy and history ${ }^{28}$.

They are otherwise characterized by default of mobility - or when evidences or stability contradict the views of a world "in flows". Scandinavian anthropologist Ulf Hannerz has, for instance, suggested that the world today, today more than ever, is replete with borders and limits, both mental and physical - as opposed to the idea of "global mobility" of people and ideas ${ }^{29}$. Moreover, academic spheres have extended the thinking of territories and spaces, of Globalization, and come up with genuine theoretical models. Among the "new geographies" of cultures, societies and religions, systemic geography looks at the physical locations of global systems dynamics, and of societies and

${ }^{27}$ Doreen Massey, For Space (London: Sage, 2005).

${ }^{28}$ Kim Knott, "Spatial Theory and Method for the Study of Religion," Temenos 41/2 (2005): 153-184.

${ }^{29}$ Ulf Hannerz, "Frontières," Revue Internationale des Sciences Sociales, 154(1997): 597-609. 
individuals in global systems. This model has led to re-examining the conceptual repertoire of geography, such as, for example, the shift from location (in "classical" geography of zones and nations) to positionality (in the geography of systems).

Furthermore, weighing against the paradigm of mobility, the global spread of meditation beyond its original Asian sources, at a much wider scale than the spread of Buddhism, and the transnationalization of South-American therapeutic cults with no connection to the expansion of Brazilian or Peruvian cultures, exemplify that while some features of religions, cultures and societies are deterritorialized, it is not the case for all features of all societies and cultures. Finally, even the fiercest promoters of "mobility" 30 and "deterritorialization"31, recognize that Globalization also produces immobility, fixity, localization, and stabilizes structures.

FLOATING THEORIES FOR FLOATING TERRITORIES:

EMPIRICAL VAGUENESS OR CONCEPTUAL FUZZINESS?

From Hannam and al.'s "mobility turn" to Doreen Massey's "spatial turn", notwithstanding Appadurai's shift from "trait geographies" to "process geographies", many models have been widely promoted by prominent scholars looking to relocate these issues to the forefront of social sciences' agenda. These new researchers should be lauded for their efforts to conciliate empirical evidence that the world is changing rapidly, and new models and methods that need to be devised to describe and understand these changes. However, the conceptual results of these emerging paradigms raise a number of epistemological questions.

Two such examples are Ulf Hannerz's concept of global cosmopolitans, namely, the community of people who live without borders, being perpetually in motion $^{32}$, and Arjun Appadurai's ethnoscapes, a descrip-

${ }^{30}$ Hannam, Sheller and Urry, "Editorial.".

${ }^{31}$ Appadurai, "Grassroots Globalization."

${ }^{32}$ Ulf Hannerz, Transnational Connections: Culture, People, Places (London: Routledge 1996). 
tive tool for the new regime of supraterritoriality ${ }^{33}$. These concepts provide models for reality that is more real than reality itself... It is true that, to a certain extent, the broadness of the contemporary context offers many examples of political, social and cultural borders being redefined. But who are the "cosmopolitans", really? Are they global jet-setting elites, or are they transnational workers and refugees? Where are the so-called "ethnoscapes", if not in our "imagination of territories", and "territories of imagination", as Appadurai himself wrote it ${ }^{34}$ ? Jonathan Friedman questioned the common acceptance of globalization as "transnationalization", and insisted upon the fact that "the transnational" was an illusion, an almost "sacred" representation of the global, leaving little room, if any, to (systemic) contradictory views ${ }^{35}$. To what extent does this multiplicity of approaches forbid the conceptualization of territories within a unique and unified framework? Given the significant oscillations between "static" and "kinetic" approaches to territories, one is left to wonder whether these "erratic theories" have been structured in such a way because they would be applied to a chaotic world. In other words, does the instability of theoretical frames correspond to the chaotic face of today's world?

As it is so difficult to establish a clear and stable conceptual framework, it is possible to conclude that theories have become erratic because they are based on observations that the world is chaotic, moving in quick and unexpected ways. Three decades ago, French anthropologist George Balandier had already pinpointed that, in a world subjected to constant changes, "traditional" methodologies based on quantitative data and cartography were not relevant anymore ${ }^{36}$. A few years later, sociologist Zigmunt Bauman has coined the term "fluid modernity"37, in similar terms that of Balandier who previously defined modernity as

${ }^{33}$ Arjun Appadurai, "Disjuncture and difference in the global culture economy," Theory, Culture, and Society. 7(1990): 295-310.

${ }^{34}$ Appadurai, "Grassroots Globalization."

${ }^{35}$ Jonathan Friedman, "From roots to routes. Tropes for trippers," Anthropological Theory 2/1 (2002): 21-36.

${ }^{36}$ Balandier, Le détour.

${ }^{37}$ Bauman, "Identity in the globalizing". 
"movement plus uncertainty" 38 . While these theories were structured by observing social and cultural (un)stability, they point at the role of the dissolution of territories in the liquefaction of societies and cultures. It is however important to highlight an overlooked argument in Balandier's theory: for the anthropologist who championed social movement and cultural volatility, a segment in hypermodern societies is more resistant than any other; namely, religion.

As it emerges, the first theoretical inconsistency in the modern or global dissolution of religious territories lies in the challenges of transposing processes and concepts: what is indeed blatant in the case of political territories is far from obvious when it comes to religious territories. An explanation of change in terms of deterritorialization is therefore not necessarily applicable to religious, cultural or religious cases. Moreover, what is a theory, if not a sometimes fuzzy discourse about indistinct objects? These objects are indeed not so distinct. The fashionable term of "deterritorialization" is more than ever associated with "reterritorialization", and the conceptual couple has become a nexus in new conceptions of religious geographies ${ }^{39}$, as well as in sociology, political sciences and anthropology ${ }^{40}$. When one territory erodes, another one is produced; and it is this alternative movement between the two poles that makes dynamic models of religious geographies more predictable.

'FLOATING' TERRITORIES, THEN? NOT THAT MUCH, ACTUALLY...

After the coming and going of theories of Modernity and Globalization, which theory of space is currently being used in Religious Studies? Today's concept of territory remains tied to a political definition of space, determined by conflicts for border appropriation and control. But

${ }^{38}$ Balandier, Le detour, 65.

${ }^{39}$ Kong, "Global shifts"; Kong, "Mapping 'new' geographies".

${ }^{40}$ Lionel Obadia, "Globalization and New Geographies of Religion. New regimes in the movement, circulation and territoriality of cults and beliefs," International Social Science Journal 63/209-210 (2014): 147-157. 
owing to "deterritorialization" processes and the paradigm of mobility, it has become a volatile reality. Was it different before? In Eliade's conception of Sacred and Profane ${ }^{41}$, a rather fuzzy theory considered "space" as a passive site for historical processes to unfold. More recently, though not in the field of religious studies, Michel Foucault developed the concept of "heterotopia"42, which proved it was possible to think the multiple ways of "making space" in the modern world. It introduced the complexity of spatial logics, rather than assuming a set ontology of places and territories. Since Lyotard (1977), "hypermodern", "postmodern" and "supermodern" conditions are seen as fluctuating, preventing the stabilization of political institutions, social habits, collective beliefs, cultural programs, ... and territories. So the very idea of "floating" is a perfect fit for the imagination of modernity. But what is a floating territory, when it comes to religion? Historically speaking, a floating territory was due to religious habits, such as pilgrimages. It was a mobility explained by religious motives, as ancient as religion in antique civilization. In what way then is religion floating because of modern or global territorial change?

Whatever causes one may attribute to religious mobility and the reshaping of territories, a key question remains: what does "floating" mean? This ambiguous metaphor yearns to be clarified. Firstly, the idea of "floating", in the very literal sense of the term that social sciences and humanities seem to admit, is synonymous with blurred empirical borders and epistemological fluidity. This "world in flows" and the corresponding fluctuating and unpredictable empirical objects and theoretical models are a source of anguish for the social sciences ${ }^{43}$.

But there are other meanings. Floating can also be seen as a nautical analogy. In that particular acceptance of the term, it does not imply complete mobility nor fluidity. With this metaphor, movement takes place underneath the stability on the surface. The "floating" refer-

${ }^{41}$ Mircéa Eliade, Le sacré et le profane (Paris: Gallimard, 1950).

${ }^{42}$ Michel Foucault, Des espaces autres. Architectures. Mouvements. Continuité, n ${ }^{\circ}$, octobre 1984, 46-49 (Republished in Dits et écrits, t. IV, n³60)

${ }^{43}$ Roland Robertson, Globalization. Social Theory and Global Culture (London: Sage, 1992). And Appadurai, "Grassroots Globalization." 
ence hereby reintroduces stability at the heart of instability, and sets up relativity in the so-called mobility paradigm. Another meaning of "floating" is geographic in nature, but yet again, at odds with the "mobility turn". It indeed designates not the dissolution of space, but a transitory state between two steady, albeit non definite, states. The catchphrase "shifting locations" is based on this particular acceptance. But what are the theoretical consequences of this conceptual locution? Does it involve shifting from old to new theories accordingly? Or does it only call for a reframing of older geographic models by focusing on processes $^{44}$ ?

Finally, to touch upon a much discussed author and theory, namely, Samuel Huntington, the "clash of civilizations" 45 includes territorial aspects, which I have called a tectonic of "civilizational plates"46. Along similar lines, though with a very different perspective, Matthias Middel and Katja Naumann recently revisited the theory of Globalization, considering it not as purely historical processes, but as the emergence through time of "new regimes of territorialization", i.e. the changing modes and rhythms of geographic dynamics ${ }^{47}$.

\section{RELIGION AND TERRITORY: (DE)TERRITORIES - (RE)LOCALIZED?}

Let us now take a close look at the theme of "religion and territory", even for just a brief outline of the issues in such a vast field of reflexion. Under the influence of Modern and Global perspectives, religion in the global context of "deterritorialization" has undoubtedly offered fertile grounds to revise classical theories in Religious Studies. This owes to the unmissable religious changes on a global scale: the Southern expansion of Roman Catholicism, the Western diffusion of Buddhism and Hindu-

${ }^{44}$ Pierre Deffontaines, Géographie et religions (Paris: Gallimard, 1948).

${ }^{45}$ Samuel Huntington, "The clash of civilisations," Foreign Affairs, summer (1993): 22-49.

${ }^{46}$ Obadia, "Globalization and New Geographies".

${ }^{47}$ Matthias Middell and Katja Naumann, "Global History and the spatial turn: from the impact of area studies to the study of critical junctures of globalization," Journal of Global History 1(2010): 149-170. 
ism, the Eastern spread of Islam, the Global spread of Pentecostalism, etc. These processes perfectly fit the fashionable concepts of "deterritorialization" and "detraditionalization". In these cases, mobility and spatial dynamics have disjointed religions from their territories. Michel de Certeau alluded to this when he asserted that "once the Church was organizing a ground, i.e. a soil..."48. In a parallel stroke, processes of transnationalism (and migration) led Meintel and Leblanc ${ }^{49}$ to assert that religion had definitely turned "nomadic", that the path of Globalization had shaped new "religioscapes" 50 , although bypassing borders is not a new religious phenomenon ${ }^{51}$. So the concept of territory is delineated by a certain type of variations: it does not spring from differences in the shape, form or nature of territories sacred or religious, but from traditional models of religious territories being altered. As such, there should be a unique and shared model of religious territory, as there has always been.

"Traditional" mobility is however still effective, and even more so than expected: (reinvented and invented) pilgrimages mix with other forms, such as religious nomadism and spiritual tourism. "Spaces", "Sites", "Places", remain key concepts and "nodes" of information on human networks: the local embeddedness of global forces ("globalization") bring to the front the resistance of "places" against "non-places"; and the "virtual" world of digital cultures and religions" ${ }^{52}$ also participates in both deterritorialization ${ }^{53}$ and reterritorialization ${ }^{54}$. In what way do these dynamics apply to the coexistence of traditional and modern forms? What is their dialectical relationship? Is the realm of religion

${ }^{48}$ Michel de Certeau, La faiblesse de croire (Paris: Editions du Seuil, 1987), 299.

${ }^{49}$ Deirde Meintel, Marie Nathalie LeBlanc, "La mobilité du religieux à l'ère de la globalisation," Anthropologie et sociétés XXVII/1 (2003): 5-11.

${ }^{50}$ Waters, Globalization.

${ }^{51}$ Beyer, Religion and Globalization.

${ }^{52}$ Christopher Helland, "Online-religion/religion-online and virtual communitas," in Religion on the Internet: Research prospects and promises, ed. Jeffrey K. Hadden and Douglas E. Cowan (New York: JAI Press, 2000).

${ }_{53}$ Olivier Roy, "La communauté virtuelle. L'internet et la déterritorialisation de l'islam," Réseaux 18/99 (2000): 219-237.

54 Obadia, "Globalization and New Geographies". 
half-deterritorialized, or half-territorialized? Does it oscillate between the two poles?

\section{EPISTEMOLOGICAL ISSUES}

Hypothetically, let us agree with Massey that social sciences and humanities are experiencing a "spatial turn". Beyond the fashionable and topical appeal of "mobility" and "spatiality", is there a bias in the discussion? In my opinion, there is not one, but four biases. The first one could be called a "theological bias": deterritorialization processes are indeed set up based on the monotheistic model and vicissitudes of Western Christianity over the past two centuries. French historian Alain Corbin showed that in France, the sense of territory for religious communities was patterned by the sonic reach of the church bell ${ }^{55}$. Similarly, de Certeau's idea that religion is losing ground ${ }^{56}$ is based on the model of the "Parish". This has served as the yardstick with which current sociology measures modern changes in religions beyond Christianity ${ }^{57}$. But such a broad generalization presents challenges: can the "modern" and global transformations of Christianity apply indistinctly to Buddhism or Islam? The "grand narratives" of Modernity and Globalization indeed raise suspicion in the minds of anthropologists who study religion ${ }^{58}$. In that sense, it appears unreasonable to consider another "grand narrative" - namely, the return of "space" and "territory" in societies, cultures and religions - as relevant in and of itself.

The second bias pertains to methodology, and is applicable in three different cases - which makes it a triple bias, with three subcategories, rather than a single one. Firstly, according to the "geographic turn", space is now everywhere, when it used to be nowhere... But was it

${ }^{55}$ Alain Corbin, Les cloches de la Terre (Paris: Albin Michel, 1994).

${ }^{56}$ De Certeau, La faiblesse de croire.

${ }^{57}$ In terms of "alteration", see Danièle Hervieu-Léger, La religion pour mémoire (Paris: le Cerf, 1993) and Danièle Hervieu-Léger, La religion en miettes ou la question des sectes (Paris: Calmann-Lévy, 2001).

${ }^{58}$ Robert Hefner, "Multiple modernities: Christianity, Islam and Hinduism in a Globalizing Age," Annual Review of Anthropology 27(1998): 83-104. 
really so? Hardly. I also doubt that the above-mentioned spatial dynamics are a "discovery". Secondly, years before the return of "space", "territory" and "geography" in global perspectives, Henri Lefebvre's Production of Space ${ }^{59}$ and Michel de Certeau's Poetics of Space ${ }^{60}$ pointed out that we study spatial processes rather than objects, and that space was nothing more than the construction of a specific narrative of reality. These pioneering works influenced Lily Kong's theory of Poetics and Politics of Space (Kong, 2001, 2010) and Arjun Appadurai's focus on the Imagination of Territories (Appadurai 2001). Thirdly and finally, the methodologies are becoming more and more sophisticated: with these new perspectives on religions, new geographic tools have been elaborated. But what has really changed: territories themselves, or the methodological tools to study them?

\section{CONCLUSIVE REMARKS}

Undoubtedly, territoriality has become a controversial concept for social sciences and humanities. It divides scholars into two opposing camps: those who defend it, and those who oppose it, depending on whether they associate Globalization with flows (the diffusionist approach) or with structure (the systemic approach). Weighing against the theory of deterritorialization however, is the fact that territorial processes are still operative, and organize people's and societies' cultural and religious lives. They however work in complex ways, and it should be taken into account that they merge with networks and flows. While they are not entirely dissolved, they are nevertheless affected by the new technologies of human circulation and cultural diffusion, as well as economic transfers and political transnational systems.

It is certainly relevant to maintain a critical attitude towards new theoretical models that align with a one-sided theory. This is especially necessary when they are structured within Globalization Studies, where

${ }^{59}$ Henry Lefebvre, La production de l'espace (Paris: Anthropos, 1974).

${ }^{60}$ Michel de Certeau, L'invention du quotidien. 1 Arts de faire (Paris: Gallimard, 1980). 
the antagonistic models of movement and stability coexist ${ }^{61}$. Do religions have floating territories? Of course they do. As for floating modern territories of globalized religions, the answer is not so definite. And as a very final conclusion, the relevance of spatial analysis, of approaches in terms of territories, must be evaluated against the prominent model of mobility. It is only by confronting their respective contributions, that the dynamics of stability and movement will be truly understood.

\section{REFERENCES}

Appadurai, Arjun. "Disjuncture and difference in the global culture economy." Theory, Culture, and Society 7(1990): 295-310.

Appadurai, Arjun. "Grassroots Globalization and the Research Imagination."

In Globalization, edited by Arjun Appadurai, 1-21. Durham, London: Duke

University Press, 2001.

Augé, Marc. Non-Lieux. Introduction à une anthropologie de la surmodernité.

Paris: le Seuil 1992.

Balandier, George. Le détour. Paris: Fayard 1985.

Bauman, Zygmunt. Liquid Modernity. Cambridge: Polity 2000.

Bauman, Zygmunt. "Identity in the globalising world." Social Anthropology 9/02 (2001): 121-129.

Beyer, Peter. Religion and Globalization. London: Sage 1994.

Beyer, Peter. "The Religious System of Global Society: a Sociological Look at Contemporary Religion and Religions." Numen 45(1998): 1-29.

Blunt, Allison. "Cultural Geographies of Migration: Mobility, Transnationality and Diaspora." Progress in Human Geography 31/5 (2007): 684-694.

de Certeau, Michel. L'invention du quotidien. 1 Arts de faire. Paris: Gallimard, 1980.

de Certeau, Michel. La faiblesse de croire. Paris: Editions du Seuil, 1987.

Clifford, James. "Travelling Cultures." In Cultural Studies, edited by Lawren-

ce Grossberg, Cary Nelson, and Paula Treichler, 96-116. New York: Routledge, 1992.

Corbin, Alain. Les cloches de la Terre. Paris: Albin Michel, 1994.

Csordas, Thomas J. "Modalities of transnational transcendence." In Modalities of transnational transcendence. Essays on Religion and Globaliza-

${ }^{61}$ Obadia, "Globalization and New Geographies". 
tion, edited by Thomas J. Csordas, 1-29. Berkeley, Los Angeles, London: University of California Press, 2009.

Debray, Régis. Dieu, un itinéraire, Paris: Odile Jacob, 2001.

Deffontaines, Pierre. Géographie et religions. Paris: Gallimard, 1948.

Eliade, Mircéa. Le sacré et le profane. Paris: Gallimard, 1950.

Foucault, Michel. Des espaces autres. Architectures. Mouvements. Continuité, n5, octobre 1984, 46-49 (Republished in Dits et écrits, t. IV, n³60).

Friedman, Jonathan. Cultural Identity and Global Process. London: Sage, 1994.

Friedman, Jonathan. "From roots to routes. Tropes for trippers." Anthropological Theory 2/1 (2002): 21-36.

Guillén, Mauro. "Is globalization civilizing, destructive or feeble? A critique of five key debates in the social science literature." Annual Review of Sociology 27(2002): 235-260.

Hannam, Kevin, Mimi Sheller, and John Urry. "Editorial: Mobilities, Immobilities and Moorings." Mobilities 1(2006): 1-22.

Hannerz, Ulf. Transnational Connections: Culture, People, Places. London: Routledge, 1996.

Hannerz, Ulf. "Frontières." Revue Internationale des Sciences Sociales 154(1997): 597-609.

Helland, Christopher. "Online-religion/religion-online and virtual communitas." In Religion on the Internet: Research prospects and promises, edited by Jeffrey K. Hadden and Douglas E. Cowan, 205-224. New York: JAI Press, 2000.

Hefner, Robert. "Multiple modernities: Christianity, Islam and Hinduism in a Globalizing Age." Annual Review of Anthropology 27(1998): 83-104.

Hervieu-Léger, Danièle. La religion pour mémoire. Paris: le Cerf, 1993.

Hervieu-Léger, Danièle. La religion en miettes ou la question des sectes. Paris: Calmann-Lévy, 2001.

Huntington, Samuel. "The clash of civilisations." Foreign Affairs, summer (1993): 22-49.

Knott, Kim. "Spatial Theory and Method for the Study of Religion." Temenos 41/2 (2005): 153-184.

Kong, Lily. "Mapping 'new' geographies of religion: politics and poetics in modernity." Progress in Human Geography 25/2 (2001): 211-233.

Kong, Lily. "Global shifts, theoretical shifts: Changing geographies of religion." Progress in Human Geography 34/6 (2010): 755-776. 
Meintel, Deirde, Marie Nathalie LeBlanc. "La mobilité du religieux à l'ère de la globalisation." Anthropologie et sociétés XXVII/1 (2003): 5-11.

Lefebvre, Henry. La production de l'espace. Paris: Anthropos, 1974.

Liogier, Raphaël. Souci de soi, Conscience du Monde: vers une religion Globale?. Paris: Armand Colin, 2012.

Luca, Nathalie. "Borrowings go Round and Round. Transcending Borders and Religious Flexibility." Diogenes 47/187 (1999): 3-10.

Massey, Doreen. For Space. London: Sage 2005.

Middell, Matthias, and Katja Naumann. "Global History and the spatial turn: from the impact of area studies to the study of critical junctures of globalization." Journal of Global History 1(2010): 149-170.

Obadia, Lionel. "Globalization and New Geographies of Religion. New regimes in the movement, circulation and territoriality of cults and beliefs." International Social Science Journal 63/209-210 (2014): 147-157.

Obadia, Lionel. "Globalization and the Sociology of Religion." In The New Companion for the Sociology of Religion, edited by Bryan Turner, 477-497. Oxford: Blackwell, 2010.

Ritzer, George. The Globalization of Nothing. Thousand Oaks: Pine Forge Press, 2004.

Robertson, Roland. Globalization. Social Theory and Global Culture. London: Sage, 1992.

Roy, Olivier. Globalized Islam: The Search for a New Ummah. New York: Columbia University Press, 2004.

Roy, Olivier. "La communauté virtuelle. L'internet et la déterritorialisation de l'islam," Réseaux 18/99 (2000): 219-237.

Tomlinson, John. Globalization and Culture. Chicago: University of Chicago Press, 1999.

Warnier, Jean-Pierre. La mondialisation de la culture. Paris: La Découverte, 1999. Waters, Malcolm. Globalization, 2nd edition. London: Routledge 2001. Zuckerman, Phil (Ed.). Atheism and Secularity. Vol. 1: Issues, Concepts and Definitions. Santa-Barbara, Denver, Oxford: Praeger/ABC-Clio, 2010.

Zuckerman, Phil (Ed.), Atheism and Secularity. Vol. 2: Global Expressions. Santa-Barbara, Denver, Oxford, Praeger/ABC-Clio, 2010. 


\section{ZMIENNE TERYTORIA RELIGII: \\ ZMIENIAJĄCE SIĘ PARADYGMATY, BŁĘDNE TEORIE \\ I NIESTABILNE REALIA?}

\section{Streszczenie}

Autor artykułu podejmuje próbę zarysu problemu «terytorium» i innych powiązanych kategorii pojęciowych, takich jak «przestrzeńn, w religioznawstwie. Na podstawie ostatnio wydanych jak i starszych publikacji, krytycznie odnosi się do bieżących debat na temat dwuznacznego statusu «terytorium». W takich dyskusjach świat jest ogólnie opisany jako kulturowe i religijne przepływy poddane procesom deterytorializacji. Wymogiem współczesności jest jednak uczynienie $\mathrm{z}$ «przestrzeni» $\mathrm{i}$ «terytorium» pierwszoplanowych przedmiotów zainteresowania nauk społecznych i religioznawstwa, co znajduje uzasadnienie w racjach o charakterze empirycznym i teoretycznym. Wydaje się, że zmieniające się paradygmaty «deterytorializacji» z jednej strony i swego rodzaju «zwrot przestrzenny» z drugiej, wynikają z epistemologicznych nieścisłości, a nie z solidnej, empirycznie potwierdzonej obserwacji rzeczywistości religijnych. Stąd też Autor formułuje szereg krytycznych ocen dotyczących przeciwnych paradygmatów «deterytorializacji» $\mathrm{i}$ «zwrotu przestrzennego».

\section{Ttumaczenie: Anna Sieradzka-Wawryszczuk}

Słowa kluczowe: terytorium, globalizacja, nowoczesność, deterytorializacja, religia $\mathrm{w}$ przestrzeni publicznej, pluralizm religijny

Key words: territory, theories, globalization, modernity, deterritorialization, religion in public space, religious pluralism 